Bangladesh J. Bot. 42(2): 287-294, 2013 (December)

\title{
SEASONALITY OF PHYTOPLANKTON PRODUCTIVITY OF THE RIVER TURAG OF DHAKA IN RELATION TO ITS WATER QUALITY
}

\author{
Moniruzzaman KhondKer* and Syeda Gousia Abed \\ Department of Botany, University of Dhaka, Dhaka-1000, Bangladesh \\ Key words: Phytoplankton, Productivity, Eutrophication, Assimilation numbers, \\ Water quality
}

\begin{abstract}
A total of 16 water quality parameters together with the phytoplankton biomass as chlorophyll $a$ and potential primary productivity of the river Turag of Bangladesh were measured for one year (July 1994 - June 1995). Potential primary productivity ranged from 6.22 - $199.7 \mu \mathrm{gC} / \mathrm{l} / \mathrm{hr}$ which showed a closer peak with total phytoplankton. Chlorophyll $a$, phosphate-phosphorus and nitrate-nitrogen concentration of the river ranged from 1.84 - 162.8, 30.28 - 796.54 and 27.02 - $905.04 \mu \mathrm{g} / \mathrm{l}$, respectively. A decrease in the mean concentration of these parameters in monsoon was seen compared to their high concentration in pre-monsoon period, which however, increased again in post-monsoon and winter. In the one hand, strong positive correlation was observed between primary productivity and chl $a$, on the other hand, chl $a$ showed strong positive correlation with phosphate-phosphorus and nitrate nitrogen. Significant negative correlation between dissolved oxygen (DO) and phosphate-phosphorus indicates the eutrophic nature of the river. This effect was minimized in monsoon. Concentration of phosphate-phosphorus, nitrate-nitrogen and chl $a$ remained high in pre-monsoon period but reduced by 90,87 and $97 \%$, respectively in monsoon. Besides, DO recovered $90 \%$ in monsoon compared to its pre-monsoon concentration. Within a span of one and a half decade, the concentration of $\mathrm{PO}_{4}-\mathrm{P}$ and $\mathrm{NO}_{3}-\mathrm{N}$ in the water has increased 4 - and 32-fold, respectively.
\end{abstract}

\section{Introduction}

Dhaka metropolis is bounded from northwest side by the river Turag, northeast side by Baloo and Sitalakhya and extreme south side by Buriganga. It is a fastest growing and densely populated (45000 ind/sq. km) city. In each decade, the population figure of this city has been jumping at a rate of 1.5-fold thereby increasing the pressure on the water quality of its surrounding rivers by the same pace. The rivers at circumference of the metropolitan receive pollutants of varying type and concentration all over the year. The study of water quality of Baloo, Buriganga, Sitalakhya and Dhaleshwari has shown pollution condition (GOB 1993, Ahmed 1993, Bari and Badruzzaman 2007). The flow of the river system in monsoon is considered enough to dilute the waste discharged but in dry seasons the dilution is tremendously reduced (Khan et al. 2007, Hasan et al. 2013). The average BOD of Dhaka city domestic sewage is about $180 \mathrm{mg} / \mathrm{l}$ which requires two times reduction by an efficient treatment plant prior to river disposal. Concentrations of $\mathrm{Cd}, \mathrm{Pb}$, and $\mathrm{Cr}$ were found higher in different stations in the course of Burignaga, Sitalakhya and Turag rivers (Alam et al. 1993).

The catchment of river Turag is occupied by nearly one third of the total population of Dhaka. Anthropogenic interferences at Amin Bazar Bridge point of the river Turag is severe but there is no water quality data available from this point. Department of Environment has published a few limnological parameters from a upstream point of the river Turag beginning from 1981, but those

*Author for correspondence: <mkhondker@yahoo.com>. 
are inadequate and highly irregular on a seasonal scale (Tongi Railway Bridge point, GOB 1993). In the recent past, sporadic information on some physicochemical variables including the concentration of some heavy metals on the river Turag have been published (Hasan et al. 2013, Sikder et al. 2012). But, information related to the seasonality of physicochemical and planktonic variables and their interrelationships culminating into biomass and productivity is totally absent. Considering this knowledge gap, though the present research was carried out in 1994-1995, attempt was undertaken to answer the research questions on the seasonal cycles of the potential biomass and productivity, effect of seasonality on the self-purification capacity of the river and the trend of annual concentration of key nutrients enhancing the plankton population and their interrelationships.

\section{Materials and Methods}

The study was carried out at the southern side of Mirpur Bridge on the river Turag at Amin Bazar (Fig. 1). Turag is a narrow and short river. It originates as a side channel from the river Bangshi near north-western part of Gazipur and reaches Tongi. At Tongi, this channel divides into two, one flows eastward direction as river Baloo while the other towards westward direction as river Turag. The river crosses Mirpur Bridge on Dhaka Aricha Highway at Amin Bazar and finally merged into Buriganga. It demarcates the western boundary of Dhaka Metropolis. The confluence zone of river Turag with Buriganga dries up during March and April when waste assimilation capacity of the river decreases.

The sampling was carried out mostly fortnightly from a fixed station in the middle of the river between July, 1994 and June, 1995 (Fig. 1). During the period, a total of 23 samplings were carried out. Water samples were collected using a Schindlers sampler (5 liter capacity) from the top half meter depth of the river and the temperature of the water was recorded from the mercury thermometer housed in the sampler. Secchi depth and water current were measured by using a Secchi disc and a Pitot tube, respectively (Welch 1948). A dark canister of 5 liter capacity was filled with the river water and brought to the laboratory along with all other samples. Daily radiation was measured from sunrise to sunset at hourly intervals using the LI-190SB sensor and radiometer. $\mathrm{pH}$ and conductivity of the river water was measured with TOA Electronics $\mathrm{pH}$-meter and an Aqualytic AL-52 conductivity meter. Alkalinity was determined after Mackereth et al. (1978) and dissolved oxygen (DO) and soluble reactive silicate (SRS) after Wetzel and Likens (1979), phosphate-phosphorus $\left(\mathrm{PO}_{4}-\mathrm{P}\right)$ and nitrate nitrogen $\left(\mathrm{NO}_{3}-\mathrm{N}\right)$ after Murphy and Rilley (1962) and Müller and Wiedemann (1955). Chl $a$ and phaeophytin were determined after Marker et al. (1980). Phytoplankton was collected by sedimentation technique with Lugol's solution and for zooplankton 10 liter of river water was passed through a plankton net (Nitex, $55 \mu \mathrm{m}$ mesh aperture) and then fixed by buffered formalin. Quantification of plankton was done following Wetzel and Likens (1979).

Light and Dark bottle $\mathrm{O}_{2}$ technique was used to determine the rate of gross primary productivity of phytoplankton (Wetzel and Likens 1979). The incubation was carried out in a white ceramic open air flow through aquarium $(78.5 \times 18.5 \mathrm{~cm}$, water depth $21.2 \mathrm{~cm})$ placed on the roof of Botany Department, Dhaka University. Ambient photosynthetic active radiation (PAR) and the temperature of the aquarium over the period of incubation ranged from 178 - 1408 $\mu \mathrm{E} / \mathrm{m}^{2} / \mathrm{sec}$ and $23.2-33.0^{\circ} \mathrm{C}$, respectively. After incubating the samples for a definite period (5-6 hrs) reagents were added for carrying out the oxygen determination.

Pearson's correlation analysis has been performed among the recorded variables by using SPSS 16.0 for Windows. 


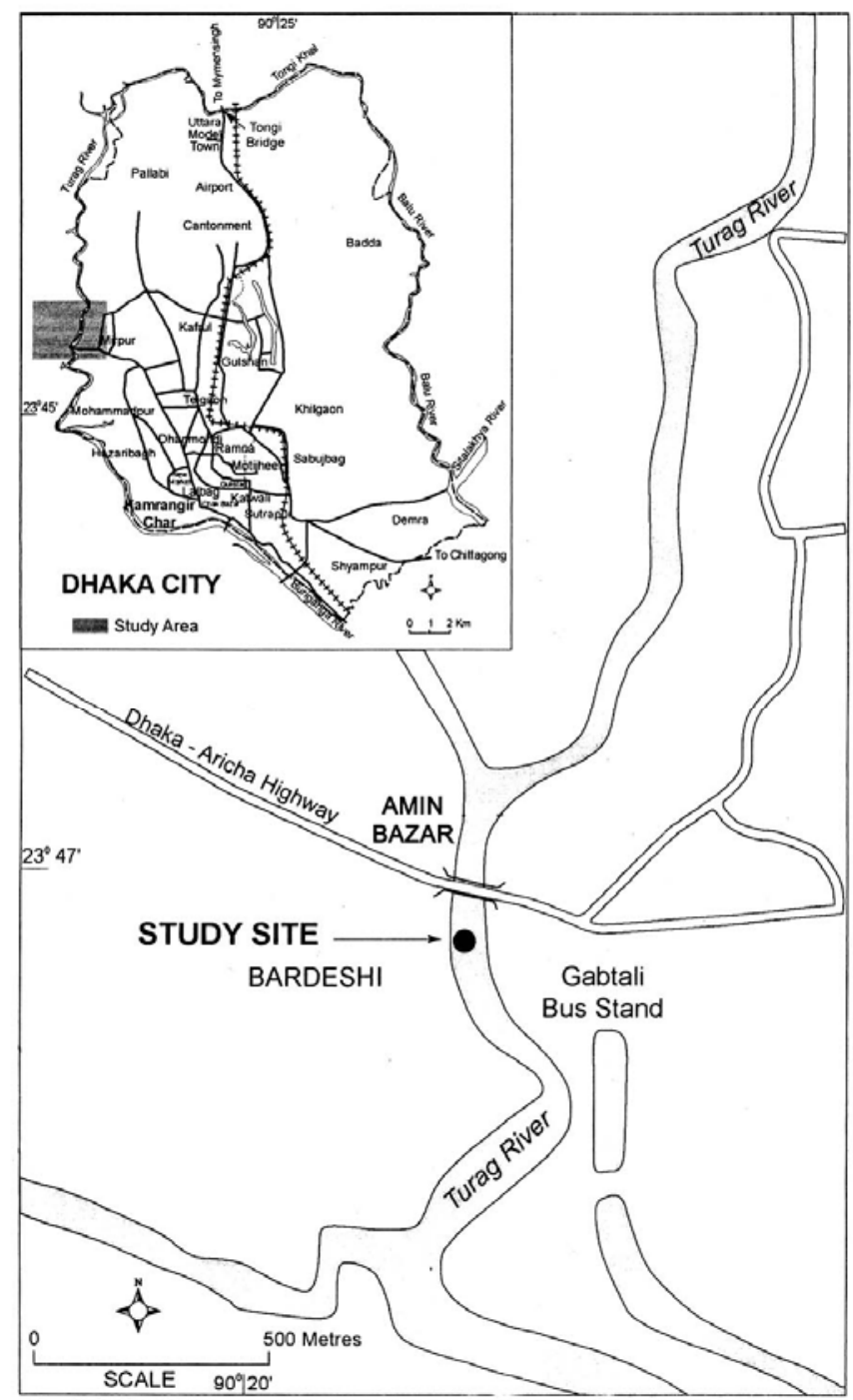

Fig. 1. Map of the study site indicating the sampling station (•) of the river Turag (inset: Dhaka city, enlarged: study site; modified after Graphosman World Atlas).

\section{Results and Discussion}

During rainy season, river Turag merges with vast areas of floodplain on both of its banks whereas in dry season the river becomes narrow. The fluctuation of different limnological parameters on an annual scale has been presented in Figs 2 and 3. Water temperature ranged from $19.5-31.5^{\circ} \mathrm{C}$ which started increasing after February until May. From June to October it ranged $28.5-31.2^{\circ} \mathrm{C}$, thereafter it started decreasing till it reached its minimum value by the end of January (Fig. 1a). Islam et al. (1974) recorded a range of water temperature $2-3^{\circ} \mathrm{C}$ higher in river Buriganga compared to Turag. Secchi disc $\left(Z_{s}\right)$ transparency in Turag ranged $20-50 \mathrm{~cm}$ and in a 
highly fluctuating manner in different months (Fig. 1a). Alkalinity and conductivity showed their clear peak concentration in April (Fig. 2b). Conductivity showed a relatively lower range (110 $890 \mu \mathrm{S} / \mathrm{cm}$ ) compared to some of its upstream stations studied in the recent years. However, the mean conductivity of the river water has increased by $7 \%$ in the recent time (Sikder et al. 2012). The $\mathrm{pH}$ ranged from $6.56-8.20$, which did not fluctuate much annually (Fig. 2c). The annual mean value as recorded in the present investigation is almost same as that reported by Sikder et al. (2012).

(a)

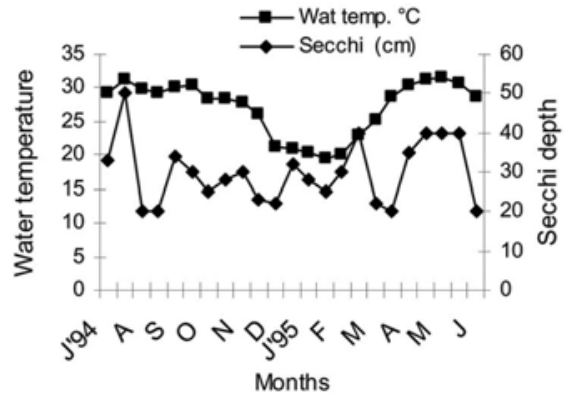

(c)

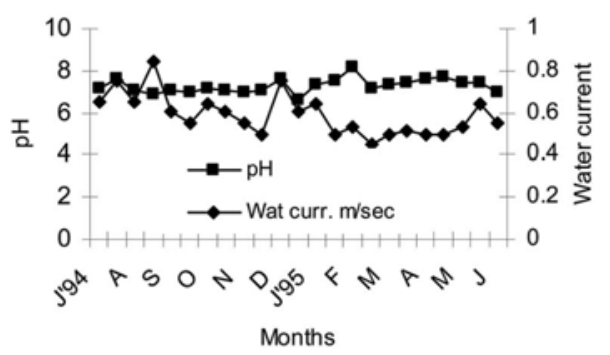

(e)

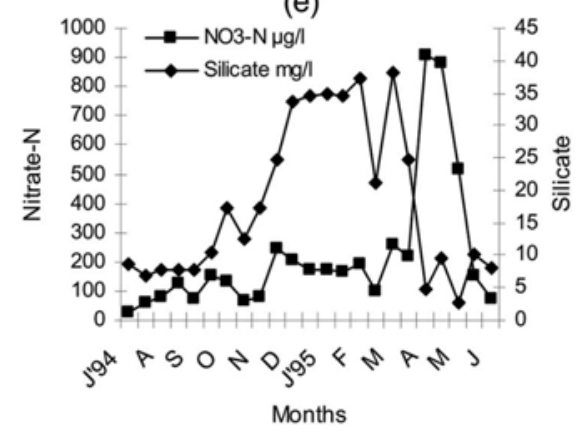

(b)

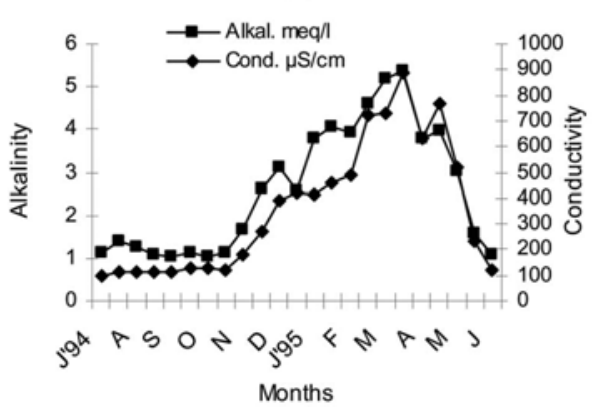

(d) $\rightarrow-D \mathrm{mg} / 1$

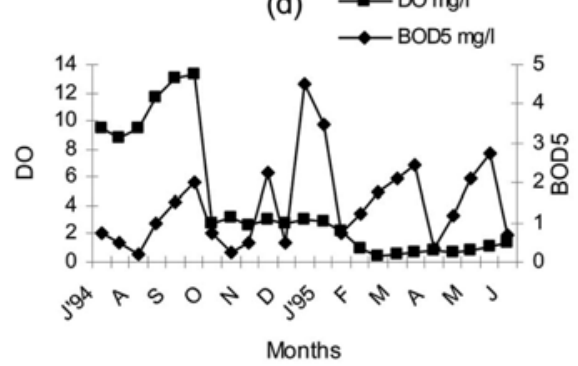

(f)

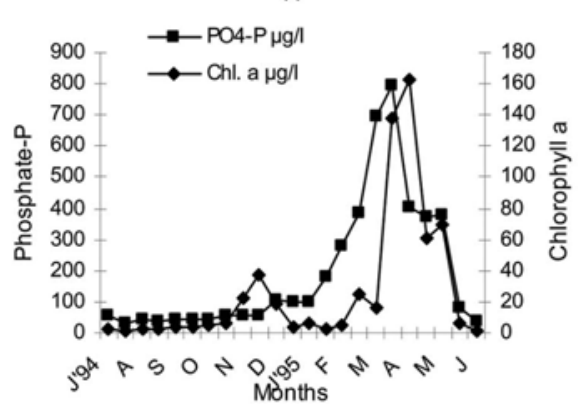

Fig. 2. Seasonal sequences in the concentration of water quality related parameters of the river Turag. (a): water temperature and transparency, (b): alkalinity and conductivity, (c): $\mathrm{pH}$ and water current, (d): dissolved oxygen and $\mathrm{BOD}_{5}$, (e): nitrate-nitrogen and silicate and (f): phosphate-P and chl $a$.

Dissolved oxygen concentration ranged from $0.45-13.3 \mathrm{mg} / \mathrm{l}$. A much lower DO range has been reported by Hasan et al. (2013). $\mathrm{BOD}_{5}$ ranged from $0.2-4.5 \mathrm{mg} / \mathrm{l}$ showing at least four peak concentrations throughout the year thus indicating a frequent bacterial load in the river water (Fig. 
2d). Recent BOD values in the river is nearly 8.68-fold more (Hasan et al. 2013) than those recorded during the year 1994 - 1995. In Turag, nitrate nitrogen ranged annually from 27-905 $\mu \mathrm{g} / \mathrm{l}$ showing a single peak in May (Fig. 2e). Recent upper limit concentration of nitrate-nitrogen of the river Turag is $1000 \mu \mathrm{g} / \mathrm{l}$ (Rahman and Hossain 2008). Chl $a$ ranged from $1.84-162.8 \mu \mathrm{g} / \mathrm{l}$ which is higher compared to other rivers. Phytoplankton biomass (chl $a$ ) and $\mathrm{PO}_{4}-\mathrm{P}$ each showed single and closer peak concentration (Fig. 2f). $\mathrm{PO}_{4}$-P became high in April which followed an immediate chl $a$ peak in May (Fig. 2f). Phaeophytin concentration also showed an identical peak concentration with that of chl $a$ and $\mathrm{PO}_{4}-\mathrm{P}$ (Fig. 3c).

(a)

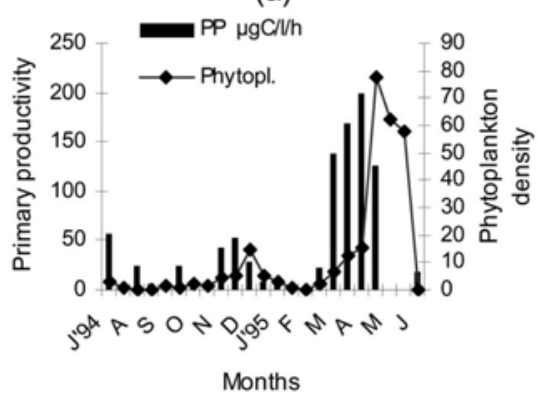

(b)

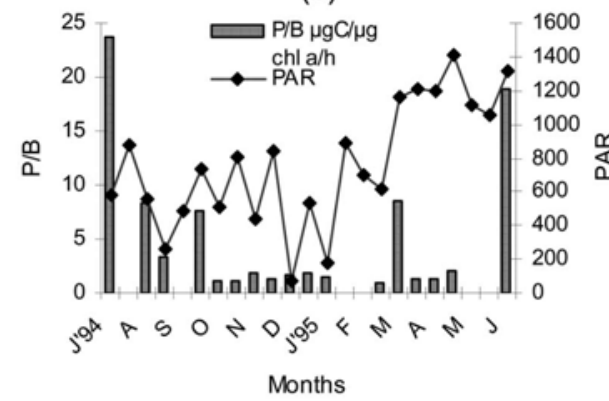

(c)

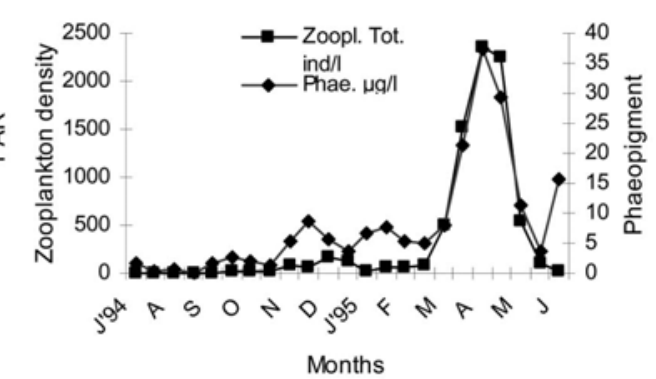

Fig. 3. Seasonal variation of primary productivity and the related parameters of the river Turag. (a): primary productivity and phytoplankton density $(\times 10000)$, (b): photosynthetic efficiencies $(\mathrm{P} / \mathrm{B})$ and photosynthetic active radiation (PAR $\mu \mathrm{E} / \mathrm{m}^{2} / \mathrm{sec}$ ) and (c): zooplankton density and phaeo-pigment.

Phytoplankotn community showed a range of potential primary productivity from $0.02-0.05$ mg $\mathrm{O}_{2} / \mathrm{l} / \mathrm{hr}$. The values were converted to carbon units (APHA 1985). It yielded 6.2 - 199.7 $\mu \mathrm{gC} / \mathrm{l} / \mathrm{hr}$ and showed a closer peak with that of total phytoplankton concentration (Fig. 3a). Ahmed and Alfasane (2004) reported a range 105.0 - $592.5 \mu \mathrm{gC} / \mathrm{l} / \mathrm{hr}$ at Mawa Ghat of the river Padma. The mean primary productivity is nearly 4 -fold lower than the river Meghna (Ahmed et al. 2005). The photosynthetic efficiency (P/B) in Turag ranged $0.88-23.77 \mu g C / c h l ~ a / l / h r$ indicating an almost inactive biomass to a theoretically maximum possible efficiency i.e., 25 $\mu g C / c h l ~ a / l / h r$ (Flakowski 1981). P/B remained highly fluctuating showing no similarity with that of photosynthetic active radiation (Fig. 3b). The concentration of zooplankton is a biological water quality parameter. In the present investigation total zooplankton density ranged 1 - 2362 ind/l and showed an overlapping peak with that of phaeophytin (Fig. 3c). It shows a heavy grazing pressure by zooplankton over phytoplankton. 
All data recorded annually, has been segmented into four seasons (Bramer 2002) and presented in Table 1. Clear seasonality for all the parameters has been observed in the river (Table 1). PAR, water temperature, conductivity, SRS, $\mathrm{NO}_{3}-\mathrm{N}, \mathrm{PO}_{4}-\mathrm{P}$, chl $a$, phytoplankton, zooplankton and primary productivity were high in pre-monsoon period compared to the other three seasons (Table 1). However, water current, $\mathrm{P} / \mathrm{B}$ ratio and dissolved oxygen which were low in premonsoon, increased satisfactorily in monsoon (Table 1). From the seasonal pattern analysis of the data, it is quite evident that monsoonal rainfall affects the river water quality tremendously. Concentration of the key

Table 1. Seasonal mean values of different parameters of the river Turag.*

\begin{tabular}{|c|c|c|c|c|}
\hline \multirow[t]{2}{*}{ Parameters } & \multicolumn{4}{|c|}{ Climatic seasons of Bangladesh } \\
\hline & $\begin{array}{l}\text { Pre-monsoon } \\
\quad(n=6)\end{array}$ & $\begin{array}{c}\text { Monsoon } \\
(n=7)\end{array}$ & $\begin{array}{l}\text { Post-monsoon } \\
\quad(n=4)\end{array}$ & $\begin{array}{l}\text { Dry or Winter } \\
\quad(n=6)\end{array}$ \\
\hline Water temperature $\left({ }^{\circ} \mathrm{C}\right)$ & $30.5(1.11)$ & $29.77(0.81)$ & $27.73(1.08)$ & $20.82(1.18)$ \\
\hline Secchi depth (cm) & $35(8.66)$ & $29.5(12.03)$ & $26.5(3.11)$ & $29.5(6.25)$ \\
\hline Alkalinity (meq/l) & $3.55(1.39)$ & $1.17(0.13)$ & $1.62(0.71)$ & $3.67(0.72)$ \\
\hline Conductivity ( $\mu \mathrm{S} / \mathrm{cm})$ & $608(253.42)$ & $110.83(6.66)$ & $175(68.56)$ & $480.83(122.41)$ \\
\hline $\mathrm{pH}$ & $7.53(0.12)$ & $7.13(0.25)$ & $7.09(0.09)$ & $7.38(0.54)$ \\
\hline Water current (m/sec) & $0.54(0.06)$ & $0.68(0.10)$ & $0.57(0.06)$ & $0.58(0.11)$ \\
\hline DO (mg/l) & $0.84(0.17)$ & $8.97(4.07)$ & $2.88(0.22)$ & $2.04(1.07)$ \\
\hline $\mathrm{BOD}_{5}(\mathrm{mg} / \mathrm{l})$ & $1.77(0.99)$ & $0.78(0.44)$ & $0.94(0.90)$ & $2.04(1.61)$ \\
\hline $\mathrm{PO}_{4}-\mathrm{P}(\mu \mathrm{g} / \mathrm{l})$ & 405.25 (254.47) & $42.37(9.34)$ & $51.26(5.41)$ & $190.72(117.60)$ \\
\hline $\mathrm{NO}_{3}-\mathrm{N}(\mu \mathrm{g} / \mathrm{l})$ & $534.19(354.49)$ & $72.95(31.27)$ & $129.65(80.60)$ & $167.34(37.12)$ \\
\hline Silicate (mg/l) & $10.33(8.65)$ & $7.81(0.50)$ & $17.92(5.03)$ & $32.64(5.75)$ \\
\hline Chlorophyll $a(\mu \mathrm{g} / \mathrm{l})$ & $87.29(62.88)$ & $2.35(1.03)$ & $18.06(15.30)$ & $10.15(9.33)$ \\
\hline $\mathrm{PP}$ mg $\left(\mathrm{O}_{2} / \mathrm{l} / \mathrm{hr}\right)$ & $0.26(0.25)$ & $0.05(0.06)$ & $0.07(0.06)$ & $0.03(0.03)$ \\
\hline $\mathrm{PP}(\mu \mathrm{gC} / \mathrm{l} / \mathrm{hr})$ & $98.86(93.96)$ & $17.65(21.38)$ & $27.41(24.03)$ & $11.33(11.87)$ \\
\hline $\mathrm{P} / \mathrm{B}(\mu \mathrm{gC} / \mu \mathrm{g}$ chl $a / \mathrm{hr})$ & $0.90(0.90)$ & $9.08(10.11)$ & $1.40(0.38)$ & $0.99(0.84)$ \\
\hline Phytopl. total (× 10000/l) & $45.1(29.28)$ & $0.92(1.15)$ & 3.35 (1.96) & $4.25(5.37)$ \\
\hline Zooplankton total (ind/l) & $1356.4(1008.86)$ & $4.33(5.96)$ & 41.75 (30.99) & 86.5 (51.79) \\
\hline $\operatorname{PAR}\left(\mu \mathrm{E} / \mathrm{m}^{2} / \mathrm{sec}\right)$ & $1196.8(134.63)$ & $680(370)$ & $649.75(203.53)$ & $498(314)$ \\
\hline Phaeopigment $(\mu \mathrm{g} / \mathrm{l})$ & $20.68(1352)$ & $3.36(6.05)$ & $4.30(3.35)$ & $5.67(1.36)$ \\
\hline Incubation temperature $\left({ }^{\circ} \mathrm{C}\right)$ & $31.42(1.40)$ & $29.38(1.30)$ & $28.55(0.66)$ & $25.78(1.32)$ \\
\hline
\end{tabular}

*Standard deviation of each seasonal mean values has been provided in parenthesis. $n=$ number of sample. Annual total sampling 23.

water quality parameters such as $\mathrm{PO}_{4}-\mathrm{P}, \mathrm{NO}_{3}-\mathrm{N}$ and chl $a$ which remained high in pre-monsoon period, reduced by 90, 87 and 97\%, respectively in monsoon (Table 1). Besides, DO recovered $90 \%$ in monsoon compared to its pre-monsoon concentration (Table 1). Khan et al. (2007) also stated a safe economic application of river and floodplain water during monsoon.

$\mathrm{Chl} a$ was found to be a function of alkalinity, conductivity, $\mathrm{PO}^{4}-\mathrm{P}$ and $\mathrm{NO}_{3}-\mathrm{N}$ (Table 2). It indicates that the availability of raw materials like carbon compounds, phosphorus, nitrogen and other ions in the river water enhances the concentration of planktonic chl $a$. It showed a negative relationship with water current but a positive relationship with phaeopigment, PAR and zooplankton density (Table 2). Since, water current washes away the biomass therefore, a negative relationship existed between chl $a$ and water current. Positive relationship among chl $a$, 
phaeopigment and zooplankton population can be explained by a positive and selective effects of grazing by zooplankton. Positive effects of grazing results increased growth rates of phytoplankton via nutrient regeneration that could potentially offset the negative effects of grazing mortality (Elser et al. 1987). At the time of grazing a degree of size and selectivity also exists among the grazing zooplankton. Such selectivity can lead to a competitive advantage among phytoplankton. Primary productivity showed a direct positive correlation with the phytoplankton biomass (chl $a$ ). However, the density of phytoplankton showed a positive relationship with nitrate nitrogen concentration. Zooplankton related strongly with the concentration $\mathrm{PO}^{4}-\mathrm{P}$, nitrate and chl $a$ (Table 2).

Table 2. Result of Pearson's correlation (r) analysis among $\mathrm{PO}_{4}-\mathrm{P}, \mathrm{NO}_{3}-\mathrm{N}$ and phytoplankton biomass $(\mathrm{chl} a)$ with other related parameters from Turag river $(n=23)$.

\begin{tabular}{lccc}
\hline Parameters & $\mathrm{PO}_{4}-\mathrm{P}$ & $\mathrm{NO}_{3}-\mathrm{N}$ & $\mathrm{Chl} a$ \\
\hline Water temperature & -0.027 & 0.195 & 0.261 \\
Secchi depth & -0.065 & 0.27 & 0.066 \\
Alkalinity & $0.835^{* *}$ & $0.450^{*}$ & $0.524^{*}$ \\
Conductivity & $0.886^{* *}$ & $0.598^{* *}$ & $0.646^{* *}$ \\
Water current & $-0.530^{* *}$ & -0.393 & $-0.425^{*}$ \\
$\mathrm{DO}$ & $-0.521^{*}$ & -0.403 & -0.4 \\
$\mathrm{BOD}_{5}$ & 0.208 & 0.042 & 0.004 \\
$\mathrm{PO}_{4}-\mathrm{P}$ & - & - & $0.681^{* *}$ \\
$\mathrm{NO}_{3}-\mathrm{N}$ & $0.470^{*}$ & - & $0.712^{* *}$ \\
$\mathrm{SRS}$ & 0.27 & -0.15 & -0.16 \\
$\mathrm{Primary}$ productivity & $0.739^{* *}$ & $0.635^{* *}$ & $0.809^{* *}$ \\
$\mathrm{P} / \mathrm{B}$ & -0.14 & -0.25 & -0.23 \\
Phytoplankton density & 0.294 & $0.646^{* *}$ & 0.34 \\
Zooplankton density & $0.650^{* *}$ & $0.888^{* *}$ & $0.860^{* *}$ \\
PAR & $0.554^{* *}$ & $0.517^{*}$ & $0.498^{*}$ \\
Phaeopigment & $0.589^{* *}$ & $0.856^{* *}$ & $0.848^{* *}$ \\
\hline
\end{tabular}

*Correlation is significant at the $0.05 \%$ level, ** at the $0.01 \%$ level.

Water temperature, Secchi disc transparency, P/B and SRS did not show any correlation with the key nutrients and phytoplankton biomass. The ranges recorded in the concentrations of $\mathrm{PO}_{4}-\mathrm{P}$, $\mathrm{NO}_{3}-\mathrm{N}$ and chl $a$ for Turag clearly shows its nature of eutrophication. When the data of the present investigation is compared with Sikder et al. (2012), it has been seen that within a span of one and one half decade or so, the concentration of $\mathrm{PO}_{4}-\mathrm{P}$ and $\mathrm{NO}_{3}-\mathrm{N}$ in the water of river Turag has increased by $4-$ and 32-fold, respectively. Fecal contamination via increasing anthropogenic activities in the catchment could be the main reason for it. At a seasonal scale, accumulation of high concentration of nitrate and phosphorus in pre-monsoon triggers phytoplankton population accompanied with a high concentration of chl $a$ (Table 1). This effect gets reduced during monsoon but increases subsequently through post-monsoon and winter (Table 1). So, monsoon season actually playing a big role in the self purification capacity of the river, hence any change in the monsoonal pattern in the region due to climate change will affect the self purification capacity of the running water ecosystems of Bangladesh.

\section{References}

Ahmed A and Alfasane MA 2004. Ecological studies of the River Padma at Mawa Ghat, Munshiganj II. Primary productivity, phytoplankton standing crop and diversity. Pak. J. Biol. Sci. 7(11): 1870-1875.

Ahmed KKU, Ahmed SU, Halder GC, Hossain MRA and Ahmed T 2005. Primary production and fish yield estimation in the Mehna River System, Bangladesh. Asian Fisheries Science 18: 95-105. 
Ahmed MF 1993. The effect of bio-degradable organic pollutants on aquatic ecosystem of the river Buriganga. In: Hypertrophic and Polluted Freshwater Ecosystems: Ecological bases for water Resources Mangagemnt (Tilzer MM and Khondker M eds). Proc. Int. Symp. Limnol., Botany Dept. Dhaka Univ. Bangladesh. pp. 97-108.

Alam AMS, Haque ANME, Ali MY, Tarafdar SA and Khan AH 1993. Heavy element contaminants in aquatic ecosystems. In: Hypertrophic and Polluted Freshwater Ecosystems: Ecological bases for water Resources Mangagemnt (Tilzer MM and Khondker M eds). Proc. Int. Symp. Limnol., Botany Dept. Dhaka Univ. Bangladesh. pp. 91-96.

APHA 1985. Standard Methods for the Examination of Water and Wastewater. 16th Edn. (Franson MAH ed.). American Public Health Association. Washington DC. pp. 1268.

Bari MF and Badruzzaman ABM 2007. Water quality mapping around Dhaka city. www. assess_hkh.at/downloads/meeting5/session3_BD_river_quality_map_Badruzzaman.pdf

Brammer H 2002. Land use and Land use Planning in Bangladesh. Univ. Press Ltd. pp. 554.

Elser JJ, Goff NC, MacKay NA, St. Amand AL, Elser MM and Carpenter SR 1987. Species specific algal responses to zooplankton: Experimental and field observations in three nutrient-limited lakes. J. Plankton Res. 9: 699-717.

Falkowski PG 1981. Light-shade adaptation and assimilation number. J. Plankton Res. 3: 203-216.

GOB 1993. Government of the People's Republic of Bangladesh. Water quality data of rivers Buriganga, Meghna, Balu, Sitalakhya, Jamuna (1981-90). Dept. Env. Dhaka. pp. 313.

Hasan MK, Hasan MK and Hossain A 2013. A comparative study of water quality in the peripheral rivers of Dhaka city. Dhaka Univ. J. Biol. Sci. 22(2): 127-136.

Islam AKMN, Haroon AKY and Zaman KM 1974. Limnological studies of the river Buriganga. I. Physical and chemical aspects. Dhaka Univ. Stud. B, 22(2): 99-111.

Khan MAI, Hossain AMMM, Huda ME, Islam MS and Elahi SF 2007. Physicochemical and biological aspects of monsoon waters at Ashulia for economic and aesthetic applications: Preliminary studies. Bangladesh J. Sci. Ind. Res. 42(4): 377-396).

Mackereth FJH, Heron J and Talling JF 1978. Water analysis: some revised methods for limnologists. Freshwat. Biol. Assoc. Sci., Publ. No. 36. pp. 120.

Marker AFH, Nusch EA, Rai H and Riemann B 1980. The measurement of photosynthetic pigments in freshwaters and standardization of methods: conclusions and recommendations. Arch. Hydrobio. Beih. Ergebn. Limnol. 14: 91-106.

Müller R and Wiedemann F 1955. Die Bestimmung des Nitrats in Wasser. Jahrbuch fuer Wasserchemie und Wasserreinigungtech. 12: 247-271.

Murphy J and Rilley RP 1962. A modified simple solution method for the determination of phosphate in natural water. Anal. Chim. Acta. 27: 31-36.

Rahman S and Hossain F 2008. Spatial assessment of water quality in peripheral reivers of Dhaka city for optimal relocation of water intake point. Water Resour. Manage. 22: 377-391.

Sikder MT, Yasuda M, Yustiawati, Syawal SM, Saito T, Tanaka S and Kurasaki M. 2012. Comparative assessment of the water quality in the major rivers of Dhaka and West Java. IJEP 2(4): 8-13

Welch PS 1948. Limnological Methods. McGraw-Hill Book Co. Inc. New York. pp. 381.

Wetzel RG and Likens GE 1979. Limnological analysis. WB Saunders Co., Philadelphia. pp. 357.

(Manuscript received on 10 January, 2013; revised on 6 October, 2013) 